\title{
The Effect Of CEO Change On Information Asymmetry
}

\author{
Sungkyu Sohn, Yonsei University, Korea \\ Yunsook Oh, Yonsei University, Korea \\ Minjung Kang, Yonsei University, Korea \\ Changhyun Bae, Yonsei University, Korea
}

\begin{abstract}
This study investigated the relationship between CEO changes and information asymmetry. In the first year after a CEO change, management ability is evaluated in an atmosphere of high pressure and scrutiny regarding company performance. In such circumstances, CEOs selectively disclose information in an effort to inflate their performance evaluation. In addition, new CEOs influence not only management decisions, but also information disclosure strategies related to both financial and nonfinancial information. Therefore, the motivations of new CEOs regarding information disclosure can increase information asymmetry, and financial analysts must put extra effort toward reducing this asymmetry. This study measured information asymmetry by the unfaithful disclosure firm designation and analyst forecast errors. The sample is composed of firms active in the Korea Composite Stock Price Index (KOSPI) from 2006 to 2009. We found that there is a significant positive relationship between CEO change and information asymmetry as measured by unfaithful disclosure firm designation and analyst forecast errors. These results imply that CEO turnover increases information asymmetry due to managers' intentional efforts to reduce the level of available information.
\end{abstract}

Keywords: CEO Change; Information Asymmetry; Analyst Forecast Error

\section{INTRODUCTION}

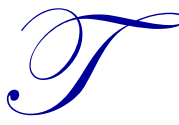

his study examines the effect of chief executive officer (CEO) changes on information asymmetry, using unfaithful disclosure firm designation ${ }^{1}$ and analyst forecast errors as proxies for information asymmetry.

Most CEO changes occur as a result of disciplinary action for a mishandling of business affairs (Coughlan \& Schmidt, 1985; Weisbach, 1988; Jensen \& Murphy, 1990; Denis \& Denis, 1995). Incoming CEOs have a strong responsibility to recover firm performance and increase earnings. Denis and Denis (1995) found that forced changes to top management are followed by significant increases in operating improvements. These changes also accompany large declines in employment, capital expenditures, and total assets. Weisbach (1995) studied the relationship between management turnover and divestitures of recently acquired divisions, finding that the probability of selling a poorly performing acquisition increases whenever a management change occurs, regardless of whether it is the result of retirement or resignation. In this sense, CEO turnover, whether voluntary or involuntary, is important in improving company performance, as the new CEO corrects the errors of the former CEO. The new CEO also attempts to establish new policies that reflect his/her perspective and capabilities. Changes that can be forecasted, such as choices regarding core business and marketing techniques, firm slogans, and general strategies, usually occur whenever a new CEO is appointed.

A new CEO influences not only crucial management decisions, but also strategies for the disclosure of information about the firm, including financial and nonfinancial information. Therefore, the disclosure approach

\footnotetext{
${ }^{1}$ The score imposed as a result of the unfaithful disclosure designation was utilized to evaluate the degree of information asymmetry. The relevant regulation and designation procedure are described in the appendix. 
(e.g. disclosure procedure and quality and quantity of the disclosed information) that a firm follows is anticipated to change when a new CEO is appointed, making it difficult for investors to interpret the related information. Information asymmetry is expected to increase in such circumstances given the diminished ability of financial analysts to search for and analyze information. The accuracy of analysts' earnings forecasts depends on disclosed accounting information (Barron et al., 1998; Kasznik \& McNichols, 2002), which is calculated based on a firm's accounting process and disclosure system. Due to the change of the financial information and related process/system, accuracy of financial analyst forecasting can decrease (Eddy \& Seifert, 1992).

In addition, when a disclosure policy is selected to maximize the utility of the firm's management, a greater degree of information asymmetry may result. In the first year after a CEO change, management ability is evaluated from both outside and within the corporation in an atmosphere of high pressure and scrutiny regarding company performance. New CEOs are likely to selectively disclose information in an effort to inflate their performance assessment or conceal information about personal performance, potentially worsening the degree of information asymmetry. In particular, previous studies (Jung, 1992; Francis et al., 1996; Lee et al., 2007, 2009) have reported that intensive earnings management actions, which impact on the earnings quality disclosed, occur during CEO turnover years.

Meanwhile, the quality of information disclosed during CEO turnover years can either increase or decrease. Voluntary disclosure theory hypothesizes that managers, facing the risk of job loss due to poor stock and earnings performance, are likely to use corporate disclosures to reduce the likelihood of undervaluation of, and to explain away, poor earnings performance (Healy \& Palepu, 2001). In addition, according to Sheikholeslami et al. (1998), financial analyses will result in reducing the level of information asymmetry by inducing additional caution and effort on the part of managers. Despite the variety of opinions concerning the relationship between CEO changes and information asymmetry, there has been little empirical research into this topic.

In this study, we measure the information asymmetry caused by a CEO change, examining analyst forecast errors and unfaithful disclosure designation in hypothesis 1 (H1) and hypothesis 2 (H2), respectively. We empirically research the effect of a CEO change from the standpoint of information asymmetry. Our results are based on samples of Korea Composite Stock Price Index (KOSPI) Market nonfinancial firms between 2006 and 2009. The final firm-year observation total 949 and 2,403, respectively, for the $\mathrm{H} 1$ and $\mathrm{H} 2$. The frequency of the explanatory variable, CEO_Change, is 292 (31.1\%) in the H1 sample and $683(28.42 \%)$ in the H2 sample.

The empirical results are as follows. For hypothesis 1, we include CEO_Change and control variables to examine the relationship between CEO_Change and analyst forecast errors. For companies with CEO changes, analyst forecast errors increase due to deficient information disclosure to investors. With respect to hypothesis 2 , companies with CEO changes are more likely to be designated as unfaithful disclosure firms than those without CEO changes. This implies that incoming CEOs may cause information asymmetry by intentionally reducing the level of information available.

This study makes several unique contributions to the literature. First, it expands the scope of research on management turnover from earnings management to management disclosure behaviors. Focusing on the issue of information asymmetry, this study suggests that a CEO not only manages accounting, but also selectively discloses accounting information. Therefore, investors should consider earnings information in the turnover year as well as the quality of the disclosure. In particular, market participants must pay close attention to the disclosed information of firms designated as unfaithful disclosure firms, and analysts' forecasts should take into account whether a CEO change occurred. Second, after checking whether information asymmetry arose from a manager's disclosure behavior, we use unfaithful disclosure firm designation and score (penalty points), unique and direct standards by which to assess disclosure quality.

The remainder of the study is organized as follows. Section 2 discusses the related literature and presents our hypotheses. Section 3 describes our research design and the sample selection. Section 4 discusses our results and findings. Finally, conclusions and implications are provided in Section 5. 


\section{RELATED LITERATURE AND HYPOTHESES}

\subsection{Literature on CEO Turnover}

Studies on CEO turnover have had three main areas of emphasis: (1) the reason for the CEO change, (2) the market's reaction, and (3) the relationship between CEO turnover and earnings management. In this study, we expand on the third area by focusing on the quality of information.

In an environment where disciplinary mechanisms are operating, new CEOs have incentives to take actions to improve firm performance. Incoming CEOs who are under pressure to improve firm performance will have motivations and opportunities related to earnings management (Murphy \& Zimmerman, 1993; Pourciau, 1993; Denis \& Denis, 1995; Huson et al., 2004; Geiger \& North, 2006).

Some researchers have investigated whether incoming CEOs are more likely to reduce earnings in their initial year and then increase earnings in subsequent years. Murphy and Zimmerman (1993) showed that incoming CEOs take a "bath" using discretionary variables, but the discretion appears limited to firms at which poor CEO performance precedes the departure. Weisbach (1995) studied the relationship between management turnover and divestitures of recently acquired divisions, finding that the probability of divesting a poorly performing acquisition rises after the departure of a CEO. He suggested that CEO turnover is one element of the error-correction process that has evolved in corporations. Denis and Denis (1995) reported that, following a change in management, firms significantly downsize their operations and are subject to a higher rate of corporate control activities. Pourciau (1993) investigated the relationship between earnings management and non-routine executive changes, finding that new executives reduce earnings when they are first appointed, but then increase earnings in years subsequent to their appointment.

Huson et al. (2004) found that the appointment of an outside CEO, rather than one promoted from within, is associated with greater improvements in reported financial performance. As they noted, this is evidence that performance changes are positively influenced by external takeover pressure. Geiger and North (2006) found that discretionary accruals decrease significantly upon the arrival of new top management (CFO). Their results indicate that companies appointing a top management position from external sources report reductions in discretionary accruals, while companies appointing CFOs from within do not report similar reductions. According to Engel et al. (2003), this phenomenon is related to the relative weight given to accounting- and market-based performance measures in CEO turnover decisions. These authors developed a model to determine the conditions under which there is a higher association between earnings and returns, implying a greater weight on earnings in managerial incentive arrangements. According to their research, firms appear to rely on market-based measures more heavily when accounting information is less timely or market returns are less variable.

\subsection{Literature on Information Asymmetry}

Prior research on information asymmetry has suggested critical factors regarding financial analysts' forecasting errors. First, it has been reported that firm size, corporate duration, debt rate, and structure of possessions have a bearing on information asymmetry (Eddy \& Seifert, 1992). Second, it is known that disclosure quality determines the level of information asymmetry (Das et al., 1998; Bradshaw et al., 2001). Specifically, Lang and Lundholm (1996) reported that the level of disclosure can improve analysts' forecast accuracy, and Hope (2003) demonstrated that countries with higher levels of transparency have more accurate analyst forecasts. Sonu et al. (2010) argued that there is a positive and significant relationship between a low quantity of available information and analyst forecast errors.

Several prior studies have shown that the business and disclosure environment has an effect on analyst forecast errors, but there has been little empirical research on the effect of CEOs on such errors except for Sheikholeslami et al. (1998). ${ }^{2}$ Following CEO replacement, analyst forecasting error can increase due to an arbitrary disclosure attitude of the management, or due to deficiency of the information search capability of financial analysts.

\footnotetext{
${ }^{2}$ Through the analysis of variance, analyst forecast accuracy marginally increased in the CEO change sample compared to the non-CEO-change sample. This research is limited in the generalizability of its hypotheses due to the limited sample size.
} 
This study utilizes the unfaithful disclosure firm designation and penalty score as proxies for information asymmetry to evaluate the effect of a manager's disclosure attitude on information asymmetry.

There is some existing research on unfaithful disclosure. Sohn et al. (2010) used an empirical analysis to show that companies with inadequate, untimely disclosure also have many problems in periodic reporting; being designated as an unfaithful firm is positively associated with having to file a financial report restatement. Kim et al. (2010) showed that there is a positive relationship between unfaithful firms and discretionary accruals. They argued that an incoming CEO at an unfaithful firm is more likely to have a dishonorable motivation. Sohn et al. (2012) argued that auditors of unfaithful firms should take a more conservative approach, reporting opinions except "an unqualified opinion" in the auditing and internal control financial reporting review. The evidence presented above suggests that management turnover eventually raises the likelihood and amount of deviation of the financial statement from true economic earnings. Newly appointed CEOs are likely to contribute to the volatility of earnings or aggressive earnings management.

While prior studies have focused only on earnings management as it relates to management turnover and market reactions, we expand the scope of such research from earnings management to management disclosure behaviors. In this way, we shed light on information asymmetry as it relates to management turnover.

\subsection{Hypothesis Development}

After CEO turnover, choices concerning core business and marketing techniques, firm slogan, general strategies, and crucial management decisions are likely to change. Information disclosure strategies, including financial and nonfinancial information, are no exception (Denis \& Denis, 1995; Weisbach, 1995). In such circumstances, it is difficult to interpret the accounting information disclosed by management, and information asymmetry is expected to be aggravated by the diminished ability of financial analysts to search for information. Financial analysis depends on disclosed accounting information (Barron et al., 1998; Kasznik \& McNichols, 2002), and analysts' forecast accuracy will decrease in the event of a change in the accounting process and disclosure system on which the calculation of the disclosed information is based (Eddy \& Seifert, 1992; Sheikholeslami et al., 1998).

Furthermore, there may be a greater degree of information asymmetry when a disclosure policy is selected to maximize the utility of the manager. In the first year after a CEO is replaced, management ability is evaluated both outside and within the corporation in an atmosphere of high pressure and scrutiny regarding the company's performance stock price. At such times, CEOs may selectively disclose information in an effort to inflate their performance evaluation or conceal personal performance information, potentially worsening information asymmetry.

Previous studies have posited that incoming CEOs are motivated to use earnings management in such a way as to meet the pressure to improve firm performance. Meanwhile, some researchers have investigated whether incoming CEOs are more likely to reduce earnings in their initial year and then increase earnings in succeeding years (known as "big bath"). Management can intentionally report overstated or understated earnings considering individual performance.

Because new CEOs are likely to selectively disclose information to the market, we argue that incoming CEOs cause information asymmetry as well as affect earnings management. In other words, incoming CEOs are more likely to face pressure to improve performance. Because it is almost impossible, however, to achieve management skills within one year of the appointment, they are likely to postpone the evaluation of their management ability until realizing their business plan sufficiently to make earnings; there is a tendency for incoming CEOs to hesitate to disclose information, hiding earnings management, during the turnover year. Sonu et al. (2010) argued that analyst forecast errors can increase when available information is lacking.

Meanwhile, firms' disclosure activities can alleviate the problem of information asymmetry between firms and outside investors (Diamond \& Verrecchia, 1991; Kim \& Verrecchia, 1994). According to voluntary disclosure theory, CEOs in poorly performing firms more aggressively disclose information (Healy \& Palepu, 2001). Thus, when a CEO change occurs due to poor handling of business, the incoming CEO puts much effort toward being 
recognized as able by aggressively disclosing information to investors. In addition, according to Sheikholeslami et al. (1998), financial analysts have an effect on reducing the level of information asymmetry by paying attention to and putting efforts toward the replacement of a CEO.

Taking this conflict view into consideration, the quality of information in the CEO turnover year can either increase or decrease. First of all, as the level of disclosure increases, the analyst forecast becomes more accurate (Lang \& Lundholm, 1996; Sonu et al., 2010). We apply this concept to estimating the level of information disclosure. The market considers analysts to be experts who are able to analyze the intention of managers. For this reason, if firms cannot achieve the level of performance expected by analysts, this may be evidence for information asymmetry. If a new CEO aggressively discloses information, analyst forecast errors will not be large. If analyst forecast errors are larger in the turnover year than in other years, however, this suggests that a new CEO is worsening information asymmetry.

Secondly, the level of information can be assessed based on the quality of disclosure. We can broadly categorize two aspects of disclosure: timely disclosure and periodic reporting. If a CEO misrepresents information, whatever type of disclosure it may be, the disclosure's transparency will be considered deteriorated.

Korea has an 'unfaithful disclosure' regulation, which is used as a sensory device by the Korea Exchange ('KRX'), for measuring the quality of information disclosure. Being designated as an unfaithful disclosure firm means clear information asymmetry exists. Therefore, we estimate the level of information disclosure based on whether firms are designated as unfaithful disclosure firms on the CEO change. According to the conflict argument explained above, we establish two null hypotheses as follows:

Hypothesis 1: CEO change is not associated with analyst forecast errors

Hypothesis 2: CEO change is not associated with being designated as an unfaithful disclosure firm

\section{RESEARCH DESIGN AND DATA}

\subsection{Research Design}

To examine analyst forecast errors (hereafter AE), we measure the absolute value of three months of analysts' forecast consensus minus the real earnings of the company. The AE is as follows:

$\mathrm{AE} 1=($ FEPS-EPS $) / \mathrm{P}$

In the above equation, FEPS is analysts' consensus from January 1 to March $31,{ }^{3}$ EPS is real earning per share, and $\mathrm{P}$ is the adjusted market price at the beginning of the year.

Equations 2 and 3 present the regression model for testing $\mathrm{H} 1$ and $\mathrm{H} 2$, respectively. The dependent variables of Model 2 are AE1 and AE2. The dependent variables of Model 3 are Unfaith and PS. Here, Unfaith is 1 when companies are designated as unfaithful disclosure firms, 0 otherwise.

AE1 (or AE2) $t=\beta 0+\beta 1$ CEO_Change $t-1+\beta 2$ Size $t+\beta 3 \operatorname{Lev} t+\beta 4$ Growth $t+\beta 5$ Roa $t+\beta 6$ Vol $t+\beta 7 M B t+$ Fixed effects $+\varepsilon \mathrm{t}$

Unfaith (or PS) $t=\beta 0+\beta 1$ CEO_Change $t+\beta 2$ Size $t+\beta 3 \operatorname{Lev} t+\beta 4$ Growth $t+\beta 5$ Roa $t+\beta 6$ Vol $t+\beta 7 M B t+$ Fixed effects $+\varepsilon \mathrm{t}$

Where,

Unfaith $\quad 1$ if firm is designated as unfaithful disclosure firm, 0 otherwise

PS Penalty points for unfaithful disclosure firm

AE1 (|consensus EPS from $1^{\text {st }}$ January to $31^{\text {th }}$ March-actual EPS|) / beginning of the year stock price

\footnotetext{
${ }^{3}$ We used the analysts' forecasts from both January 1 to March 31 and October 1 to December 31 for robustness.
} 
AE2 (|consensus EPS from $1^{\text {st }}$ October to $31^{\text {th }}$ December-actual EPS $\left.\mid\right)$ / beginning of the year stock price

CEO_Change 1 when there is a change in the CEO in the current fiscal year, 0 otherwise

Size Natural logarithm of total assets

Lev Total debt/total assets

Growth Average change in total assets

Roa Net income/total assets

Big 1 if the company's auditor is one of the Big 4, 0 otherwise

Vol Standard deviation of daily stock return

MB Market value of equity/book value of equity

We expect that companies with a CEO change are more likely to have information asymmetry compared to firms without a CEO change. Control variables are drawn from the literature on disclosure quality and information asymmetry (Bradbury, 1992; Wallace \& Naser, 1995; Lee \& Sohn, 2005). We measure firm size by the natural logarithm of total assets (Size). Large firms are expected to voluntarily disclose more information than smaller firms in order to alleviate the information asymmetry problem that emerges as entities grow in size (Foster, 1986; Cooke, 1991; Lee \& Sohn, 2005). High leverage (Lev) firms are likely to conceal or to disclose less information to minimize legal risks (Bradbury, 1992). Growth is the average percentage change in total assets, Roa is the profitability of the company, and MB is the market-to-book ratio. When a company has experienced rapid growth or high profitability, management may be motivated to disclose more information (Wallace, 1995). Because the Big 4 auditors are more likely to restrict earnings management than non-Big 4 auditors (Becker et al., 1998; Francis et al., 1999), we include a Big 4 dummy variable (Big). Vol is the standard deviation of stock returns.

Information ambiguity can be explained through Vol concerning the information environment (Ann et al., 2006; Sonu et al., 2010). Companies experiencing greater volatility in share prices are likely to share less information about their company.

\subsection{Data and Sample Selection}

Table 1 shows the frequency distribution of observations used for $\mathrm{H} 1$ and $\mathrm{H} 2$.

Table 1: Sample Selection

\begin{tabular}{|c|c|c|c|c|}
\hline \multicolumn{5}{|l|}{ Panel A: Sample Selection Criteria } \\
\hline $\begin{array}{l}\text { Sample Selection Process } \\
\end{array}$ & \multicolumn{2}{|c|}{ H1: AE Sample } & \multicolumn{2}{|c|}{ H2:Unfaith Sample } \\
\hline Nonfinancial firm observations 2006 2009 & \multicolumn{2}{|c|}{2,958} & \multicolumn{2}{|c|}{2,958} \\
\hline (Less) Non-December 31 fiscal year end firms & \multicolumn{2}{|c|}{$(87)$} & \multicolumn{2}{|c|}{$(87)$} \\
\hline (Less) Firms with insufficient financial data & \multicolumn{2}{|c|}{$(468)$} & \multicolumn{2}{|c|}{$(468)$} \\
\hline (Less) Firm without analysts' forecast data & \multicolumn{2}{|c|}{$(1,464)$} & \multicolumn{2}{|c|}{-} \\
\hline Final Sample Size Used for H1, H2 & \multicolumn{2}{|c|}{939} & \multicolumn{2}{|c|}{2,403} \\
\hline \multicolumn{5}{|l|}{ Panel B: Samples by Year } \\
\hline \multirow{2}{*}{ Year } & \multicolumn{2}{|c|}{ H1: AE Sample } & \multicolumn{2}{|c|}{ H2:Unfaith Sample } \\
\hline & Firms & \% of Sample & Firms & \% of Sample \\
\hline 2006 & 248 & 26.41 & $585(21)$ & 24.34 \\
\hline 2007 & 243 & 25.88 & $597(13)$ & 24.84 \\
\hline 2008 & 222 & 23.64 & $594(40)$ & 24.72 \\
\hline 2009 & 226 & 24.07 & $627(17)$ & 26.09 \\
\hline Total & 939 & & $2,403(91)$ & \\
\hline \multicolumn{5}{|c|}{ * Numbers inside parentheses of Panel B: number of unfaithful disclosure firms } \\
\hline \multicolumn{5}{|c|}{ Panel C: CEO Change Firms by Year } \\
\hline \multirow{2}{*}{ Year } & \multicolumn{2}{|c|}{ H1: AE Sample } & \multicolumn{2}{|c|}{ H2:Unfaith Sample } \\
\hline & Firms & \% of Sample & Firms & \% of Sample \\
\hline 2006 & 72 & 24.66 & 186 & 27.23 \\
\hline 2007 & 94 & 32.19 & 193 & 28.26 \\
\hline 2008 & 56 & 19.18 & 142 & 20.79 \\
\hline 2009 & 70 & 23.97 & 162 & 23.72 \\
\hline Total & 292 & & 683 & \\
\hline
\end{tabular}


Samples in this study are nonfinancial firms listed on the Korean Stock Exchange from 2006 to 2009. Panel A of Table 1 shows each of the total firm-year observations for hypothesis 1 (H1) and hypothesis 2 (H2). We excluded 468 firms lacking sufficient financial data and 1,464 firms lacking analyst forecast data. Thus, the final firm-year observations totaled 939 and 2,403, respectively, as shown in Panel A of Table 1. Due to the lack of analyst forecast data, the $\mathrm{H} 1$ sample has fewer observations than the $\mathrm{H} 2$ sample. Panel B of Table 1 shows the frequency of distribution of observations by year. Specifically, the numbers inside parentheses in Panel B are the number of unfaithful disclosure firms by year. Panel $\mathrm{C}$ of Table 1 shows the frequency of the explanatory variable CEO change (CEO_Change) by year. The frequency of CEO_Change is $292(31.1 \%)$ in the H1 sample and 683 $(28.42 \%)$ in the $\mathrm{H} 2$ sample.

Firm financial data are available from the KIS-VALUE database. CEO change data were manually collected using the E-Disclosure System of the KRX. Data on analyst forecast errors were obtained from the DataGuide Pro database operated by FnGuide. Except for the dummy variable, all variables were winsorized at the top and bottom one-percentile of the pooled data.

\section{RESULTS}

\subsection{Descriptive Statistics and Correlation Analysis}

Table 2 provides the descriptive statistics regarding all variables for $\mathrm{H} 1$ and $\mathrm{H} 2$ that are used in Equations 2 and 3.

Table 2: Descriptive Statistics

\begin{tabular}{|c|c|c|c|c|c|}
\hline \multicolumn{6}{|c|}{ Panel A: AE-Based Samples ( $\mathrm{N}=939)$} \\
\hline Variables & Mean & Standard Deviation & Min & Median & Max \\
\hline$A E 1$ & 0.075 & 0.122 & 0.000 & 0.033 & 0.753 \\
\hline$A E 2 *$ & 0.029 & 0.051 & 0.000 & 0.013 & 0.337 \\
\hline CEO_Change & 0.311 & 0.463 & 0.000 & 0.000 & 1.000 \\
\hline Size & 27.583 & 1.474 & 24.564 & 27.476 & 30.569 \\
\hline Lev & 0.449 & 0.193 & 0.062 & 0.458 & 0.968 \\
\hline Growth & 0.121 & 0.239 & -0.696 & 0.096 & 2.674 \\
\hline Roa & 0.058 & 0.075 & -0.378 & 0.056 & 0.318 \\
\hline Big & 0.865 & 0.342 & 0.000 & 1.000 & 1.000 \\
\hline Vol & 3.180 & 0.929 & 1.400 & 3.019 & 8.085 \\
\hline$M B$ & 1.491 & 1.187 & 0.086 & 1.133 & 6.388 \\
\hline \multicolumn{6}{|c|}{ Panel B: Unfaith-Based Samples $(\mathrm{N}=\mathbf{2 , 4 0 3})$} \\
\hline Variables & Mean & Standard Deviation & Min & Median & Max \\
\hline Unfaith & 0.038 & 0.191 & 0.000 & 0.000 & 1.000 \\
\hline$P S$ & 0.115 & 0.772 & 0.000 & 0.000 & 6.000 \\
\hline CEO_Change & 0.288 & 0.453 & 0.000 & 0.000 & 1.000 \\
\hline Size & 26.494 & 1.505 & 23.492 & 26.202 & 30.569 \\
\hline Lev & 0.442 & 0.198 & 0.062 & 0.455 & 0.968 \\
\hline Growth & 0.121 & 0.278 & -0.696 & 0.080 & 2.674 \\
\hline Roa & 0.030 & 0.098 & -0.378 & 0.038 & 0.318 \\
\hline Big & 0.694 & 0.461 & 0.000 & 1.000 & 1.000 \\
\hline Vol & 3.474 & 1.180 & 1.400 & 3.237 & 8.085 \\
\hline$M B$ & 1.181 & 1.071 & 0.086 & 0.826 & 6.388 \\
\hline
\end{tabular}

*In the case of AE2, 792 reports a descriptive statistics for the sample. The definitions of variables: Unfaith - 1 if firm is designated as unfaithful disclosure firm, 0 otherwise. PS - Penalty points for unfaithful disclosure firm. AE1 - (|consensus EPS from $1^{\text {st }}$ January to $31^{\text {th }}$ March - actual EPS|) / beginning of the year stock price. AE2 - (|consensus EPS from $1^{\text {st }}$ October to $31^{\text {th }}$ December - actual EPS|) / beginning of the year stock price. CEO_Change - 1 when there is a change in the CEO in the current fiscal year, 0 otherwise. Size - Natural logarithm of total assets. Lev Total debt/total assets. Growth - the average change in total assets. Roa - Net income/total assets. Big - 1 if the company's auditor is one of the Big 4, 0 otherwise. $V o l$ - Standard deviation of daily stock return. $M B$ - Market value of equity/book value of equity.

Panel A provides the descriptive statistics for the AE-based sample. The frequency of the explanatory variable CEO_Change is $27.6 \%$ in the $\mathrm{H} 1$ sample. The mean value of AE1 is 0.075 , and the median value is 0.033 . The mean value of AE2 is 0.029, and the median value is 0.013. Panel B presents descriptive statistics for the 
Unfaith-based sample. The mean values of the dependent variables Unfaith and PS are 0.038 and 0.115 , respectively. Approximately $4 \%$ of the firms were designated as unfaithful disclosure firms over the entire sample period.

The size of companies in the sample presents a normal distribution because the value between the mean and the median is not large. The Lev differences between the mean and median values are also small. Regarding external auditors, $87 \%$ of the Panel A sample and $69 \%$ of the Panel B sample are Big 4 auditors, respectively. The distributions of the control variables (size, lev, growth, Roa, big, vol, MB) are generally consistent with prior Korean studies (Kang et al., 2013).

In Table 3, Panels A and B represent the Pearson correlation matrix of variables in the AE-based sample and Unfaith-based sample, respectively.

Table 3: Correlation Matrix

\begin{tabular}{|c|c|c|c|c|c|c|c|c|c|}
\hline \multicolumn{10}{|c|}{ Panel A: AE-Based Samples $(\mathrm{N}=939)$} \\
\hline & 2 & 3 & 4 & 5 & 6 & 7 & 8 & 9 & 10 \\
\hline \multirow[t]{2}{*}{ 1. $A E 1$} & 0.727 & 0.095 & 0.014 & 0.323 & -0.088 & -0.501 & -0.055 & 0.197 & -0.090 \\
\hline & $<.0001$ & 0.004 & 0.670 & $<.0001$ & 0.007 & $<.0001$ & 0.094 & $<.0001$ & 0.006 \\
\hline \multirow[t]{2}{*}{ 2. $A E 2^{*}$} & 1.000 & 0.122 & 0.048 & 0.387 & -0.093 & -0.510 & -0.035 & 0.259 & -0.110 \\
\hline & & 0.001 & 0.174 & $<.0001$ & 0.009 & $<.0001$ & 0.322 & $<.0001$ & 0.002 \\
\hline \multirow[t]{2}{*}{ 3. CEO_Change } & & 1.000 & 0.145 & 0.155 & -0.053 & -0.052 & 0.084 & 0.002 & 0.091 \\
\hline & & & $<.0001$ & $<.0001$ & 0.107 & 0.111 & 0.010 & 0.944 & 0.005 \\
\hline \multirow[t]{2}{*}{ 4. Size } & & & 1.000 & 0.333 & 0.126 & -0.064 & 0.301 & 0.029 & 0.122 \\
\hline & & & & $<.0001$ & 0.000 & 0.051 & $<.0001$ & 0.381 & 0.000 \\
\hline \multirow[t]{2}{*}{ 5. Lev } & & & & 1.000 & 0.201 & -0.440 & -0.009 & 0.290 & 0.115 \\
\hline & & & & & $<.0001$ & $<.0001$ & 0.793 & $<.0001$ & 0.000 \\
\hline \multirow[t]{2}{*}{ 6. Growth } & & & & & 1.000 & 0.240 & -0.037 & 0.203 & 0.100 \\
\hline & & & & & & $<.0001$ & 0.254 & $<.0001$ & 0.002 \\
\hline \multirow[t]{2}{*}{ 7. Roa } & & & & & & 1.000 & 0.016 & -0.169 & 0.259 \\
\hline & & & & & & & 0.614 & $<.0001$ & $<.0001$ \\
\hline \multirow[t]{2}{*}{ 8. Big } & & & & & & & 1.000 & -0.098 & 0.119 \\
\hline & & & & & & & & 0.003 & 0.000 \\
\hline \multirow[t]{2}{*}{ 9. Vol } & & & & & & & & 1.000 & -0.036 \\
\hline & & & & & & & & & 0.274 \\
\hline \multicolumn{3}{|l|}{ 10. $M B$} & & & & & & & 1.000 \\
\hline \multicolumn{10}{|c|}{ Panel B: Unfaith-Based Samples $(\mathrm{N}=\mathbf{2 , 4 0 3})$} \\
\hline \multirow{2}{*}{ 1. Unfaith } & 2 & 3 & 4 & 5 & 6 & 7 & 8 & 9 & 10 \\
\hline & 0.753 & 0.047 & -0.084 & 0.056 & 0.032 & -0.124 & -0.105 & 0.138 & -0.023 \\
\hline 1. & $<.0001$ & 0.021 & $<.0001$ & 0.006 & 0.115 & $<.0001$ & $<.0001$ & $<.0001$ & 0.269 \\
\hline \multirow[t]{2}{*}{ 2. $P S$} & 1.000 & 0.044 & -0.056 & 0.075 & 0.030 & -0.139 & -0.102 & 0.105 & 0.011 \\
\hline & & 0.030 & 0.006 & 0.000 & 0.139 & $<.0001$ & $<.0001$ & $<.0001$ & 0.584 \\
\hline \multirow[t]{2}{*}{ 3. $C E O \_C h a n g e$} & & 1.000 & 0.116 & 0.105 & -0.023 & -0.142 & 0.035 & 0.037 & 0.118 \\
\hline & & & $<.0001$ & $<.0001$ & 0.268 & $<.0001$ & 0.084 & 0.073 & $<.0001$ \\
\hline \multirow[t]{2}{*}{ 4. Size } & & & 1.000 & 0.181 & 0.126 & 0.229 & 0.389 & -0.227 & 0.120 \\
\hline & & & & $<.0001$ & $<.0001$ & $<.0001$ & $<.0001$ & $<.0001$ & $<.0001$ \\
\hline \multirow[t]{2}{*}{ 5. Lev } & & & & 1.000 & 0.084 & -0.340 & 0.025 & 0.245 & 0.185 \\
\hline & & & & & $<.0001$ & $<.0001$ & 0.221 & $<.0001$ & $<.0001$ \\
\hline \multirow[t]{2}{*}{ 6. Growth } & & & & & 1.000 & 0.118 & 0.003 & 0.115 & 0.069 \\
\hline & & & & & & $<.0001$ & 0.869 & $<.0001$ & 0.001 \\
\hline \multirow[t]{2}{*}{ 7. Roa } & & & & & & 1.000 & 0.146 & -0.352 & 0.035 \\
\hline & & & & & & & $<.0001$ & $<.0001$ & 0.084 \\
\hline \multirow[t]{2}{*}{ 8. Big } & & & & & & & 1.000 & -0.177 & 0.094 \\
\hline & & & & & & & & $<.0001$ & $<.0001$ \\
\hline \multirow[t]{2}{*}{ 9. $\mathrm{Vol}$} & & & & & & & & 1.000 & 0.107 \\
\hline & & & & & & & & & $\begin{array}{c}<.0001 \\
1000\end{array}$ \\
\hline
\end{tabular}

*In the case of AE2, 792 reports a correlation for the sample 
Panel A shows the correlation between CEO_Change and the analyst forecast error variables. There is a positive and significant relationship between CEO change and AE1 (or AE2), supporting H1 indirectly.

Panel B shows the correlation between CEO_Change and the variables of unfaithful disclosure. There is a positive and significant relationship between CEO_Change and Unfaith (or PS), although this result was obtained without controlling for the effects of other variables on Unfaith. Nevertheless, it demonstrates the higher probability of information asymmetry during the turnover year.

Despite the many correlations among variables used in the analysis, the multicollinearity problem is not serious, considering that the value of VIF (Variance Inflation Factor) is not above 2 in the regression analysis.

\subsection{Empirical Results}

Table 4 shows the regression results for analyst forecast errors following a CEO change.

Table 4: The Effect of CEO Change on Analyst Forecast Errors (H1)

\begin{tabular}{|c|c|c|c|c|c|}
\hline \multicolumn{6}{|c|}{ AE1 (or AE2) $)_{t}=\beta_{0}+\beta_{1}$ CEO_Change $e_{t-1}+\beta_{2}$ Size $_{t}+\beta_{3}$ Lev $_{t}+\beta_{4}$ Growth $_{t}+\beta_{5}$ Roa $_{t}+\beta_{6}$ Vol $_{t}+\beta_{7}$ MB $_{t}+$ Fixed effects $+\varepsilon_{t}$} \\
\hline \multirow{2}{*}{ Variables } & \multirow{2}{*}{ Expected Sign } & \multicolumn{2}{|c|}{ (1) Dep. = AE1 } & \multicolumn{2}{|c|}{ (2) Dep. = AE2 } \\
\hline & & Coefficients & t-value & Coefficients & t-value \\
\hline Intercept & ? & 0.228 & $3.31^{* * * *}$ & 0.111 & $3.49^{* * * *}$ \\
\hline CEO_Change & + & 0.018 & $2.54^{* *}$ & 0.008 & $2.55^{* *}$ \\
\hline Size & - & -0.006 & $-2.31^{* *}$ & -0.004 & $-3.08^{* * * *}$ \\
\hline Lev & + & 0.086 & $3.71^{* * * *}$ & 0.050 & $4.71^{* * * *}$ \\
\hline Growth & $+/-$ & -0.003 & -0.17 & 0.000 & -0.38 \\
\hline Roa & - & -0.670 & $-12.18^{* * *}$ & -0.273 & $-10.34^{* * *}$ \\
\hline Big & - & -0.006 & -0.62 & -0.003 & -0.52 \\
\hline Vol & + & 0.016 & $3.40^{* * * *}$ & 0.007 & $3.24^{* * *}$ \\
\hline$M B$ & - & 0.002 & 0.55 & 0.001 & 0.51 \\
\hline Industry Dummies & & \multirow{2}{*}{\multicolumn{2}{|c|}{$\begin{array}{l}\text { Included } \\
\text { Included }\end{array}$}} & \multicolumn{2}{|c|}{ Included } \\
\hline Year Dummies & & & & \multicolumn{2}{|c|}{ Included } \\
\hline \multicolumn{2}{|l|}{ F-value } & \multicolumn{2}{|c|}{$24.81^{* * * *}$} & \multicolumn{2}{|c|}{$21.48^{* * *}$} \\
\hline \multicolumn{2}{|l|}{ Adjusted-R² } & \multicolumn{2}{|c|}{0.369} & \multicolumn{2}{|c|}{0.373} \\
\hline \multicolumn{2}{|l|}{ Sample Size } & \multicolumn{2}{|c|}{939} & \multicolumn{2}{|c|}{792} \\
\hline
\end{tabular}

The dependent variable AE1 (AE2) is an absolute value of analyst forecast errors. The H1 regression model uses AE1 (AE2) samples consisting of 939 (792) firm-year observations. In the H1 model, we included CEO_Change and control variables to examine the relationship between CEO_Change and analyst forecast errors. The coefficient on CEO_Change in column (1) is positive and significant at the five percent level $(0.018$; $\mathrm{t}$-value = 2.54). The coefficient on AE2 in column (2) is positive and significant at the five percent level.

For firms with a CEO change, analyst forecast errors increase due to deficient and incorrect information disclosure to investors. Table 5 presents the regression results for unfaithful disclosure firm designation (and penalty points) in the case of a $\mathrm{CEO}$ change.

The dependent variable Unfaith is a dummy variable for an unfaithful disclosure firm in column (1) and penalty points in column (2). We used 2,403 firm-year observations to analyze $\mathrm{H} 2$.

In the $\mathrm{H} 2$ model, we included CEO_Change and control variables to examine the relationship between CEO_Change and Unfaith (and PS). Our interest lies in the sign of the coefficient on CEO_Change. The coefficient on CEO_Change in column (1) is positive and significant at the one percent level $(0.655$; Wald X2 value $=6.94)$. The coefficient on CEO_Change in column (2) is positive and significant at the ten percent level (0.059; $t$-value 1.67). 
Table 5: The Effect of CEO Change on Unfaithful Disclosure Designation (H2)

\begin{tabular}{|c|c|c|c|c|c|}
\hline \multicolumn{6}{|c|}{ Unfaith (or PS $)_{t}=\beta_{0}+\beta_{1}$ CEO_Change ${ }_{t}+\beta_{2}$ Size $_{t}+\beta_{3}$ Lev $_{t}+\beta_{4}$ Growth $_{t}+\beta_{5}$ Roa $_{t}+\beta_{6}$ Vol $_{t}+\beta_{7}$ MB $_{t}+$ Fixed effects $+\varepsilon$} \\
\hline \multirow{2}{*}{ Variables } & \multirow{2}{*}{ Expected Sign } & \multicolumn{2}{|c|}{ (1) Dep. = Unfaith } & \multicolumn{2}{|c|}{ (2) Dep. $=$ PS } \\
\hline & & Coefficients & Wald $X^{2}$ Value & Coefficients & t-value \\
\hline Intercept & $?$ & -3.431 & 1.56 & -0.111 & -0.33 \\
\hline CEO_Change & + & 0.655 & $6.94^{* * * *}$ & 0.059 & $1.67^{*}$ \\
\hline Size & - & -0.120 & 1.40 & 0.004 & 0.34 \\
\hline Lev & + & 1.081 & $2.73^{*}$ & 0.124 & 1.33 \\
\hline Growth & $+/-$ & 0.005 & 1.51 & 0.001 & 1.37 \\
\hline Roa & - & -1.020 & 0.86 & -0.756 & $-3.94^{* * * *}$ \\
\hline Big & - & -0.607 & $5.91^{* *}$ & -0.133 & $-3.54^{* * *}$ \\
\hline Vol & + & 0.315 & $8.88^{* * * *}$ & 0.035 & $2.11^{* *}$ \\
\hline$M B$ & - & -0.210 & $2.71^{*}$ & 0.003 & 0.19 \\
\hline Industry Dummies & & \multicolumn{2}{|c|}{ Included } & \multicolumn{2}{|c|}{ Included } \\
\hline Year Dummies & & \multicolumn{2}{|c|}{ Included } & \multicolumn{2}{|c|}{ Included } \\
\hline \multicolumn{2}{|c|}{ Likelihood Ratio $X^{2} / \mathrm{F}$-value } & \multicolumn{2}{|c|}{$139.44^{\text {**** }}$} & \multicolumn{2}{|c|}{$4.60^{* * * *}$} \\
\hline \multicolumn{2}{|c|}{ Pseudo $\mathrm{R}^{2} /$ Adjusted-R ${ }^{2}$} & \multicolumn{2}{|c|}{0.204} & \multicolumn{2}{|c|}{0.033} \\
\hline \multicolumn{2}{|l|}{ Sample Size } & \multicolumn{2}{|c|}{2,403} & \multicolumn{2}{|c|}{2,403} \\
\hline
\end{tabular}

Notes: ***, **, and * represent significance at the 1,5 , and 10 percent levels, respectively. Variable definitions are presented in Table 2.

These results imply that companies with a CEO change are more likely to be designated as unfaithful disclosure firms than are those without a CEO change. Thus, incoming CEOs may cause information asymmetry by intentionally reducing the level of information available.

The results of the control variables included in the model are generally consistent with our expectation, both in Table 4 and Table 5. The coefficients on size, Roa, and big are negative and significant. These results suggest that large, highly profitable firms audited by the Big 4 are less likely to be designated as unfaithful disclosure firms and are likely to have lower analyst forecast errors. The coefficient of vol is positive and significant, indicating that firms with high stock price volatility have a positive relationship with information asymmetry, as we expected.

\section{CONCLUSION}

This study examined the effect of chief executive officer (CEO) changes on information asymmetry, using unfaithful disclosure firm designation and analyst forecast errors as proxies for information asymmetry. A new CEO influences not only crucial management decisions but also strategies regarding the disclosure of information about their firms, including both financial and nonfinancial information. Therefore, a firm's disclosure strategy can be expected to change when a new CEO is appointed. In such circumstances, it is difficult to interpret the information disclosed by management. Financial analysts will have a diminished capability to search for and analyze information, and information asymmetry is expected to worsen.

In addition, when a disclosure policy is selected to maximize the utility of management, a greater degree of information asymmetry may occur. Due to intensive earnings management actions in the CEO turnover year, new CEOs are likely to selectively disclose information to the market. If a new CEO intends to hide his/her use of earnings management, the level of information asymmetry will increase.

Meanwhile, if a new CEO does not wish his/her ability to be underestimated owing to a poor performance in the first year, the level of information disclosure can increase and information asymmetry can decrease.

In this study, information asymmetry was estimated by not only analyst forecast errors but also the unfaithful disclosure firm designation. Analyst forecast errors are used as a proxy for the quality of accounting information received by analysts (Barron et al., 1998; Kasznik \& McNichols, 2002; Kang et al., 2013), while the unfaithful disclosure firm designation affords a method of directly estimating the quality of disclosure. That is, the unfaithful disclosure designation implies a serious level of information asymmetry (Sohn et al., 2012).

The analysis of analyst forecast errors revealed a large degree of error in the turnover year, as we expected. That is, an incoming CEO is likely to give as little information as possible to the market, leading to more severe 
information asymmetry. The empirical results also indicate that firms with a CEO change have a higher probability of being designated as unfaithful disclosure firms. This result implies that a new CEO causes information asymmetry in his or her attempt to hide evaluation information.

This study expands the scope of management turnover research through its focus on information asymmetry as it relates to management turnover. The findings suggest that a CEO not only manages accounting earnings but also selectively discloses accounting information. Therefore, investors should consider earnings information during the turnover year as well as the quality of the disclosure. In particular, market participants must pay close attention to the disclosed information of firms designated as unfaithful disclosure firms, and analysts' forecasts should take into account whether a CEO change occurred.

\section{AUTHOR INFORMATION}

Sungkyu Sohn, Ph.D., Professor, School of Business, Yonsei University, 50 Yonsei-ro, Seodaemun-gu, Seoul 120749, South Korea. E-mail: sksohn@yonsei.ac.kr

Yunsook Oh, Ph.D. Candidate, School of Business, Yonsei University, 50 Yonsei-ro, Seodaemun-gu, Seoul 120749, South Korea. E-mail: ohys@yonsei.ac.kr (Corresponding author)

Minjung Kang, Ph.D. Candidate, School of Business, Yonsei University, 50 Yonsei-ro, Seodaemun-gu, Seoul 120749, South Korea. E-mail: mjkang1@yonsei.ac.kr

Changhyun Bae, Ph.D. Candidate, School of Business, Yonsei University, 50 Yonsei-ro, Seodaemun-gu, Seoul 120-749, South Korea. E-mail: bae6015@yonsei.ac.kr (Corresponding author)

\section{REFERENCES}

1. Ahn, Y., Yoo, T. Y., Cho, Y. J., Shin, H. H., \& Jang, J. H. (2006). The effect of financial analysts' characteristics on earnings forecast accuracy. Korean Accounting Review, 31(4), 1-24. [Printed in Korean]

2. Bamber, L. S., Jiang, J., \& Wang, I. Y. (2010). What's my style? The influence of top managers on voluntary corporate financial disclosure. The Accounting Review, 85(4), 1131-1162.

3. Barron, O. E., Kim, O., Lim, S. C., \& Stevens, D. E. (1998). Using analysts' forecasts to measure properties of analysts' information environment. The Accounting Review, 73(4), 421-433.

4. Becker, C. L., DeFond, M., Jiambalvo, J., \& Subramanyam, K. R. (1998). The effect of audit quality on earnings management. Contemporary Accounting Research, 15(1), 1-24.

5. Bradbury, M. E. (1992). Voluntary semiannual earnings disclosures, earnings volatility, unexpected earnings, and firm size. Journal of Accounting Research, 30(1), 137-145.

6. Bradshaw, M. T., Richardson, S., \& Sloan, R. (2001). Do analysts and auditors use information in accruals? Journal of Accounting Research, 39(1), 45-74.

7. Cooke, T. E. (1991). An assessment of voluntary disclosure in the annual reports of Japanese Corporations. The International Journal of Accounting, 26(3), 174-189.

8. Coughlan, A. T., \& Schmidt, R. M. (1985). Executive compensation, management turnover, and firm performance: an empirical investigation. Journal of Accounting and Economics, 7(1-3), 43-66.

9. Das, S., Levine, C., \& Sivaramakrishnan, K. (1998). Earnings predictability and bias in analysts' earnings forecasts. The Accounting Review, 73(2), 277-294.

10. Dechow, P. M., \& Sloan, R. G. (1991). Executive incentive and the horizon problem: An empirical investigation. Journal of Accounting and Economics, 14(1), 51-89.

11. Denis, D. J., \& Denis, D. K. (1995). Performance changes following top management dismissals. The Journal of Finance, 50(4), 1029-1057.

12. Diamond, D. W. \& Verrecchia, R. E. (1991). Disclosure, liquidity, and the cost of capital. The Journal of Finance, 46(4), 1325-1359.

13. Eddy, A., \& Seifert, B. (1992). An examination of hypotheses concerning earnings forecast errors. Quarterly Journal of Business and Economics, 31(2), 22-37.

14. Francis, J., Hanna, J. D., \& Vincent, L. (1996). Causes and effects of discretionary asset write-offs. Journal of Accounting Research, 34, 117-134. 
15. Francis, J., Maydew, E. L., \& Sparks, H. C. (1999). The Role of big 6 auditors in the credible reporting of accruals. A Journal of Practice \& Theory, 18(2), 17-34.

16. Foster, G. (1986). Financial statement analysis (2nd ed.). Englewood Cliffs, NJ: Prentice-Hall.

17. Geiger, M. A., \& North, D. S. (2006). Does hiring a new CFO change things? An investigation of changes in discretionary accruals. The Accounting Review, 81(4), 781-809.

18. Healy, P. M., \& Palepu, K. G. (2001). Information asymmetry, corporate disclosure, and the capital markets: A review of the empirical disclosure literature. Journal of Accounting and Economics, 31(1-3), 405-440.

19. Hope, O. K. (2003). Disclosure practices, enforcement of accounting standards, and analysts' forecast accuracy: An international study. Journal of Accounting Research, 41(2), 235-272.

20. Huson, M., Malatesta, P. H., \& Parrino, R. (2004). Managerial succession and firm performance. Journal of Financial Economics, 74(2), 237-275.

21. Jensen, M. C., \& Murphy, K. J. (1990). Performance pay and top-management incentives. Journal of Political Economy, 98(2), 225-264.

22. Jung, K. E. (1992). Management changes and income smoothing. Korean Accounting Review, 14(1), $27-48$. [Printed in Korean]

23. Kang, M., Lee, M., \& Lee, H. Y. (2013). The impact of financial reporting comparability on analyst forecasts and value relevance. Korean Accounting Review, 38(1), 281-320. [Printed in Korean]

24. Kasznik, R., \& McNichols, M. F. (2002). Does meeting earnings expectations matter? Evidence from analyst forecast revisions and share prices. Journal of Accounting Research, 40(3), 727-759.

25. Kim, O., \& Verrecchia, R. E. (1994). Market liquidity and volume around earnings announcements. Journal of Accounting and Economics, 17(1-2), 41-67.

26. Kim. Y. C., Hwang, K. J., \& Lee, S. Y. (2010). An empirical relationship between discretionary accruals and unfaithful disclosure. Korean Accounting Journal, 19(1), 173-201. [Printed in Korean]

27. Lang, M. H., \& Lundholm, R. J. (1996). Corporate disclosure policy and analyst behavior. The Accounting Review, 71(4), 467-492.

28. Lee, A. Y., Chun, S. B., \& Park, S. S. (2007). CEO turnover and earnings management. Korean Accounting Review, 32(2), 117-150. [Printed in Korean]

29. Lee, A. Y., Chun, S. B., Park, S. S., \& Choi, J. H. (2009). The internal versus external CEO changes, the reason for the changes, and earnings management. Korean Accounting Review, 34(2), 45-78. [Printed in Korean]

30. Lee. J. W., \& Sohn, S. (2005). An empirical analysis of the relationship between corporate governance and corporate disclosure practice in Korea. Korean Accounting Review, 30(3), 33-69. [Printed in Korean]

31. Murphy, K. J., \& Zimmerman, J. L. (1993). Financial performance surrounding CEO turnover. Journal of Accounting and Economics, 16(1-3), 273-315.

32. Pourciau, S. (1993). Earnings management and nonroutine executive changes. Journal of Accounting and Economics, 16(1-3), 317-336.

33. Sheikholeslami, M., Wilson, M. D., \& Selin, J. R. (1998). The impact of CEO turnover on security analysts' forecast accuracy. The Journal of Applied Business Research, 14(4), 71-75.

34. Smith, A. (1993). Earnings and management incentives: Comments. Journal of Accounting and Economics, 16(1-3), 337-347.

35. Sohn, S., Kim, S., \& Chung, K. (2010). Empirical study of the relation between timely disclosure and periodic report: Focusing on unfaithful disclosure and prior error adjustment. Korean Accounting Journal, 19(4), 1-36. [Printed in Korean]

36. Sohn, S., Chae, S. J., \& Oh, Y. S. (2012). The effect of unfaithful disclosure designation and unfaithful disclosure penalty point on internal accounting control review and audit opinion. Korean Accounting Review, 37(1), 1-40. [Printed in Korean]

37. Sonu, C., Choi, J. H., \& Lee, B. B. H. (2010). The effect of the wedge between voting right and cash flow right on error in analysts' earnings forecasts. Korean Accounting Review, 35(2), 1-34. [Printed in Korean]

38. Weisbach, M. S. (1988). Outside directors and CEO turnover. Journal of Financial Economics, 20, 431460 .

39. Weisbach, M. S. (1995). CEO turnover and the firm's investment decision. Journal of Financial Economics, 37(2), 159-188. 


\section{APPENDIX}

The Corporate Disclosure System refers to the system that requires listed corporations to make public corporate information and business details that could influence investment decisions regarding stock prices, thus helping investors to make informed decisions. The disclosure system settles information asymmetry inside the KRX markets, enhancing fair securities trading and protecting investors.

Listed corporations should file the required disclosure items faithfully according to the Financial Investment Services and Capital Markets Act (FSCMA) and the disclosure regulations for KOSPI. Also, they have a responsibility to prevent items regarding inside information from resulting in rumors or being reported to the security market prior to the disclosure.

If listed corporations that violate the rule do not obey these disclosure duties faithfully or if they are subject to nonfulfillment, reversal, or alteration of disclosure by reversal or alteration of the filed information, they are designated as unfaithful disclosure corporations.

Unfaithful disclosure means not filing disclosure items by the due date or false disclosure; disclosure reversal is filing information of revocation, denial, or other cases accordingly; and disclosure alteration means altering material information before the due date.

If listed corporations fall under unfaithful disclosures, they are given a period of 7 days (on the basis of the selling date) to object after the designation notice of unfaithful disclosure. Unless there is no objection filed by the listed corporation within that period, the listed corporation is designated as an unfaithful disclosure listed corporation. If an objection is filed, KRX finally decides whether to designate it as an unfaithful listed corporation and imposes penalty points no later than 3 days after the review date by the KOSPI Market Listing and Disclosure Committee, whose review must be within 10 days of the last day of the objection filing period.

Penalty points imposed for unfaithful disclosure corporations can range from a minimum of 2 points to a maximum of 12 points for each case, taking into account the disclosure violation and disclosure delay period.

Once a firm is designated as an unfaithful disclosure corporation and has penalty points imposed, it is required to submit an improvement program regarding its education and announcement of sale transaction suspension, designation as an unfaithful disclosure corporation, and penalty point imposition from KXR and Financial Supervisory Service. In the event a firm is designated as an unfaithful disclosure corporation, the sale transaction suspension is effective for one day upon the designation date, and the announcement of the designation as an unfaithful disclosure corporation and penalty point imposition needs to include the list, designation cause, and penalty points in the security market or electronic disclosure system (http://kind.sm.krx.co.kr).

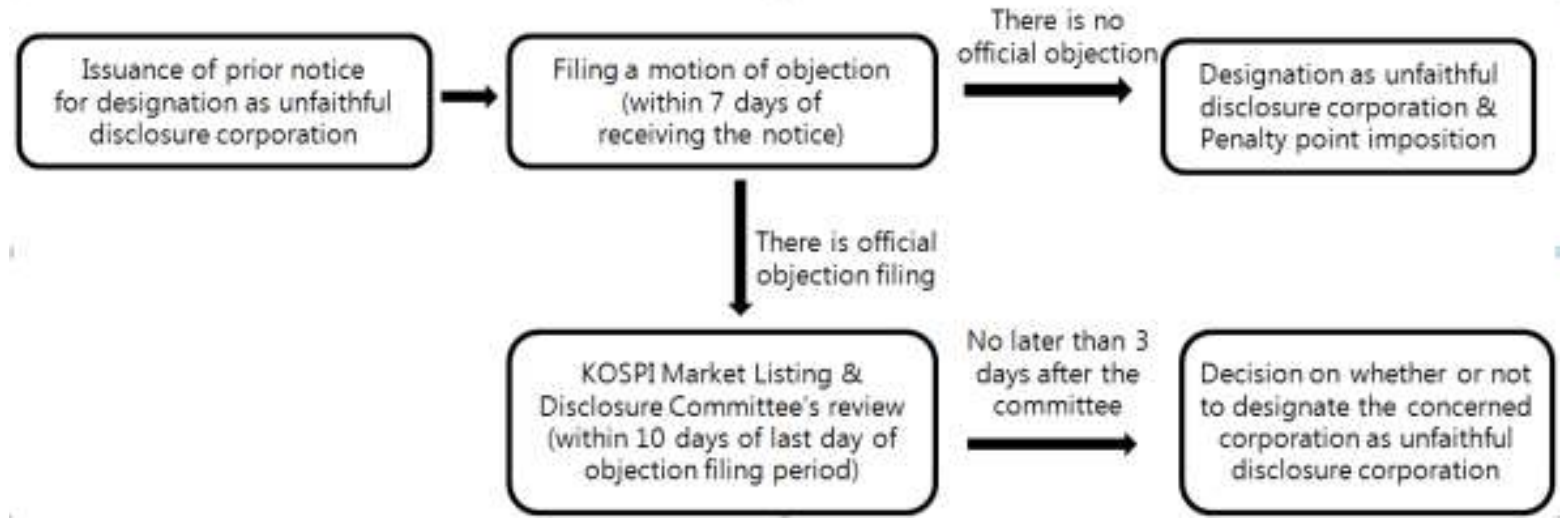

Figure 1: Procedure for Designating Unfaithful Disclosure Firms 


\section{NOTES}

